ROBERT KOŁODZIEJ

Uniwersytet Wrocławski

iD ORCID ID: 0000-0002-3900-6667
WŁADZA I POLITYKA

W CZASACH NOWOŻYTNYCH

DYPLOMACJA I SPRAWY WEWNĘTRZNE

\title{
Wpływ Jana III Sobieskiego na sejmiki ziemskie - próba interpretacji zjawiska
}

Jan III Sobieski's influence on dietines (provincial assemblies)

An attempt to interpret the phenomenon

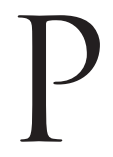

róby poza systemowego wpływania monarchów na przebieg sejmików przedsejmowych i relacyjnych to zjawisko, którego nasilenie można zaobserwować w drugiej połowie XVII w. Działania takie doceniał Jan Kazimierz, który dostrzegł, że przeforsowanie odpowiednich kandydatów na posłów oraz spisanie dla nich instrukcji zawierającej korzystne dla dworu punkty znacznie zwiększało szanse na realizację ambitnych planów politycznych. Ostatni Waza był prawdopodobnie jedynym królem elekcyjnym, który osobiście objeżdżał najważniejsze sejmiki, spotykał ze szlachtą i starał się wpływać na ich przebieg ${ }^{1}$. Posiadanie jak największej liczby zaufanych, a nawet oddanych posłów w izbie poselskiej stało się szczególnie istotne w drugiej połowie XVII w., gdy zasada jednomyślności przybiera nowe kształty, a protest jednego parlamentarzysty, przynajmniej teoretycznie, może doprowadzić do wstrzymania prac całego sejmu. Dlatego na sejmikach widać rosnącą rywalizację między dworem i opozycją, w której obie strony nie przebierają w środkach, aby zdominować sejmiki. Sytuacja w tym zakresie nie zmieniła się w czasach panowania Michała Korybuta, a antykrólewska opozycja dzięki posiadaniu w izbie silnego zaplecza mogła pozwolić sobie na zrywanie kolejnych sejmów ${ }^{2}$.

\footnotetext{
1 S. Ochmann, Sejmy z lat 1661-1662. Przegrana batalia o reformę ustroju Rzeczypospolitej, Wrocław 1977 , s. $25-27$.

2 Działania obozów politycznych na sejmikach w czasach panowania Michała Korybuta wzbudziły ostatnio zainteresowanie badaczy, które przyniosło wiele interesujących prac na ten temat, zarówno dotyczących Korony, jak i Wielkiego Księstwa Litewskiego. Z większych studiów por. przede wszystkim: J. Matyasik, Obóz polityczny króla Michata Korybuta Wiśniowieckiego, Warszawa 2011; J. Kaniewski, Sejmiki koronne wobec problemów wewnętrznych Rzeczypospolitej za panowania Michata Korybuta
} 
Jan Sobieski wstępował na tron jako jeden z czołowych przedstawicieli malkontentów, osoba o znakomitej orientacji w polityce wewnętrznej i niezwykle aktywny statysta. Toteż nie może dziwić, że doceniał prace wykonywane na sejmikach, bo to one zapewniały sprawny i skuteczny przebieg sejmu. Tymczasem z lektur najważniejszych biografii Jana Sobieskiego nie wynika, aby prowadził aktywną politykę sejmikową - koncentrując się przede wszystkim na sprawach międzynarodowych i na kwestiach związanych z wojną. Polityka wewnętrzna miała być raczej zdominowana przez opozycję $^{3}$. Zachowało się jednak sporo materiałów źródłowych, które dowodzą, że było zupełnie inaczej i pozwalają odtworzyć mechanizmy, jakimi posługiwał się król, aby skutecznie prowadzić działania na sejmikach. Bardzo przydatne w badaniach tego zjawiska są rękopisy z archiwum Sobieskich przechowywane aktualnie w Archiwum Historycznym w Mińsku. W listach kierowanych bezpośrednio do króla odnaleźć można wiele informacji związanych właśnie z sejmikami. W śledzeniu działań dworu pomaga również niezwykle cenny zbiór korespondencji Stanisława Antoniego Szczuki, królewskiego zaufanego, który nie tylko sam angażował się w życie sejmikowe, ale koordynował działania innych, zbierał informacje i przekazywał je monarsze. Sporo wniosków można wysnuć z rozproszonej korespondencji szlachty i senatorów biorących czynny udział w życiu politycznym. Wreszcie bardzo pouczająca jest lektura różnego rodzaju manifestacji i protestacji składanych w grodach, a zachowanych do dziś w księgach grodzkich, ponieważ niejednokrotnie pozwalają poznać sposoby wpływania na sejmiki.

Dla społeczeństwa szlacheckiego nie było tajemnicą, że dwór prowadził nieoficjalne działania na sejmikach. Król zresztą się z tym nie krył, tłumacząc, że postępuje „tak, jako i tamtej stronie ludzie czynią”’ . Usprawiedliwieniem były więc działania opozycji i pozostałych partii funkcjonujących w Rzeczypospolitej. W wielu przekazach znaleźć można informacje, że król przywiązywał dużą wagę do elekcji odpowiednich osób na posłów. Przed sejmami 1676-1678 zjazdy litewskich regalistów, mające na celu m.in. omówienie kampanii sejmikowej, odbywały się w Nieświeżu i Białej6. Przed pierwszym

Wiśniowieckiego (1669-1673), Katowice 2014; K. Bobiatyński, W walce o hegemonię. Rywalizacja polityczna w Wielkim Księstwie Litewskim w latach 1667-1674, Warszawa 2016; M. Sawicki, Dom sapieżyński 1666-1685. Droga do hegemonii w Wielkim Księstwie Litewskim, Opole 2016; A.A. Majewski, Aleksander Hilary Potubiński (1626-1679) marszatek wielki litewski, Warszawa 2017.

${ }^{3}$ Dwie najpełniejsze biografie króla Jana III to oczywiście wielokrotnie wznawiane prace: O. Forst de Battaglia, Jan Sobieski król Polski, Warszawa 1983; Z. Wójcik, Jan Sobieski, Warszawa 1983.

${ }_{4}^{4}$ Diariusz audiencyi u JKM przy traktamencie wielmożnego jm. pana Przeździeckiego kasztelana nowogródzkiego wypisany [VIII 1678], AGAD, AR, dz. II, sygn. 1664, s. 5.

'O niezależności posłów w omawianym okresie pisze R. Kołodziej, „Ostatni wolności naszej klejnot”. Sejm Rzeczypospolitej za panowania Jana III Sobieskiego, Poznań 2014, s. 342-346.

${ }^{6}$ D. Konieczna, Litewska kampania sejmikowa przed sejmem warszawskim 1677 roku, ,Rocznik Lituanistyczny” 2017, nr 3, s. 82; eadem, Zmagania dworu z opozycją litewska przed sejmem grodzieńskim z 1678-1679 roku, [w:] Marszatek i hetman koronny Jan Sobieski, red. D. Milewski, Warszawa 2016, s. 79. 
sejmem grodzieńskim donoszono, że „posłów na sejm dobrych życzy król [...], którzy by upomnieli się kontraweniencyjej zawziętości złych ludzi”7. W podobnym tonie pisał do marszałka litewskiego obecny na dworze królewskim sufragan smoleński Tyzenhauz: „trzebaby posłów z województw i powiatów ordynować życzliwe subiecta, sobie i Królowi JM"8. Przed sejmem 1693 r. król zaufanym senatorom podawał nawet nazwiska osób, które chciałby widzieć na funkcji poselskiej’. Aby osiągnąć zamierzony cel, należało prowadzić aktywną kampanię w całym kraju, opartą o szerokie rzesze zaufanych i związanych z dworem osób, co było zadaniem skomplikowanym i wymagającym wysiłku sporej grupy współpracowników. Najprostszą metodą było zaangażowanie do pracy sejmikowej lokalnych senatorów i zaufanej szlachty, i tak też postępował dwór.

Wbrew tezom Zbigniewa Wójcika ${ }^{10}$ istniała spora grupa senatorów zaangażowanych we wspieranie królewskich postulatów sejmikowych. Na początku panowania na sejmikach ukrainnych dla Jana III pracował Mikołaj Sieniawski ${ }^{11}$. Na sejmiku opatowskim działał w interesach króla Jan Szumowski, podskarbi nadworny, który przesyłał dla niego informacje i instrukcje spisywane dla posłów ${ }^{12}$. Zaufanym i wiernym współpracownikiem króla był Stanisław Szczuka, który, choć w tym czasie nie pełnił funkcji senatorskiej, jako regent kancelarii miał znacznie większe wpływy na dworze niż wszyscy czterej kanclerze ${ }^{13}$. Na sejmiku zatorskim w imieniu króla miał pracować chorąży krakowski Andrzej Żydowski, a na sejmiku sandomierskim Józef Karol Lubomirski, marszałek nadworny koronny ${ }^{14}$. Była również cała grupa sejmików litewskich, na których pracowali ludzie związani z dworem (Radziwiłłowie, Słuszkowie, Kryszpinowie i inni). Senatorowie oddziaływali zarówno przez swój autorytet, jak i władzę.

7 Diariusz audiencyi u JKM przy traktamencie, s. 5.

${ }^{8}$ Sufragan smoleński [Jan Tyzenhauz?] do Aleksandra Hilarego Połubińskiego, marszałka lit., Jaworów, 27 VII 1678, AGAD, AR, dz. V, sygn. 16717, s. 118-121. Zganienie miało dotyczyć przede wszystkim stronnictwa Paców, którzy nie dopuścili, wbrew konstytucji sejmowej, do rozpuszczenia wojska litewskiego.

9 Jan III do Karola Radziwiłła, podkanclerzego litewskiego, Pomorzany, 24 X 1692, BCz, rkps 183 , s. 543.

${ }^{10}$ Z. Wójcik, Jan Sobieski, s. 408. Biograf Sobieskiego niemal wszystkich senatorów traktował jako przedstawicieli opozycji.

${ }^{11}$ J. Stolicki, Wobec wolności i króla. Dziatalność polityczna szlachty ruskiej, ukrainnej i wotyńskiej w latach 1673-1683, Kraków 2007, s. 252.

${ }^{12}$ Jan Szumowski, podskarbi nadworny kor. do Stanisława Sarnowskiego, b.d. i m. [1676-1678?], BCz, rkps 1376, s. 231-232.

${ }_{13}$ I. Grochowska, Stanistaw Antonii Szczuka - jego dziatalność w ziemi wiskiej 1682-1710, Warszawa 1989; T. Zielińska, Stanistaw Antonii Szczuka jako referendarz koronny w latach 1688-1699, „Kwartalnik Historyczny" 1994, t. CXI, s. 5-22; H. Palkij, Szczuka Stanistaw Antonii (ok. 1654-1710), [w:] PSB, t. XLVII, Kraków-Wrocław 2010-2011, s. 469-481.

${ }_{14}$ S. Szczuka do Jana III, Lublin, 23 XI 1692, ANKr, Archiwum Krzeszowskie Potockich, sygn. 3360 , s. $305-315$. 
Szczególnie duże wpływy mogli mieć hetmani. Po pierwsze, z racji ściągania na sejmiki wojska, po drugie, mając możliwość pozaprawnego „wpływania” na zebraną szlachtę. Anonimowy autor w 1695 r. pisał: „skoro się kto z wolnym głosem na sejmiku nie do smaku odezwie, prędko ma po tym w domu swoim gości, jednę, dugą na konsystencyją, choćby też i w dobrach dziedzicznych, chorągiew. Kto zaś servitio promptior, tego dobra i dzierżawy nie tylko od przechodów i od leże żołnierskich wolne, ale też do respektów i nagrody bliższy"15.

Są to oczywiście opinie skrajne, bo często senatorowie samym autorytetem przyczyniali się do szczęśliwego zakończenia sejmiku. Bieliński donosił z sejmiku czerskiego, że musiał się podjąć jego marszałkowania, gdyż groziło mu zerwanie ${ }^{16}$. Autorytet senatorski mógł również skłonić zbyt ambitnego szlachcica do ustąpienia z kandydowania na funkcję poselską, jak to miało miejsce w 1692 r. na sejmiku mozyrskim ${ }^{17}$.

Nie zawsze senator przybywał na obrady osobiście - za dużo było sejmików, a za mało zaufanych senatorów. Wówczas próbował działać przez osoby trzecie. Czasem była to rodzina. Hetman Stanisław Jan Jabłonowski na sejmik wiszeński wyprawiał najczęściej swoich synów ${ }^{18}$. Częściej jednak posługiwano się „przyjaciółmi” i lokalną elitą, którą trzeba było sobie zjednać i nakłonić do współpracy, a dwór umiał to robić, mając do dyspozycji tak potężne narzędzie, jak dystrybucja dóbr i urzędów. Na podstawie fragmentów źródłowych można dostrzec, że król niejednokrotnie uzależniał rozdawanie urzędów nie tylko od zaproponowanej ceny w gotówce, ale i od zasług. Tak było np. w przypadku przywileju na chorąstwo wiskie, o którym z dworu donoszono, że „nie pierwej [król] wydać je każe, aż zobaczy qua side et modestia cum fratribus de sanguine stawać będzie na sejmiku"19. Aleksander Kazimierz Zapolski podkomorzy sieradzki starał się o stolnikostwo brzeskie dla syna, jednak awans był uzależniony od postawy na sejmiku radziejowskim, „na którym, jeśli pan Zapolski praerogativam loci ex vocis nieugoni, to pewnie straci urząd" ${ }^{20}$. Marcjan Wołłowicz zapewne za zasługi dla króla

${ }^{15}$ Kopia listu pewnego posła do sąsiada pisanego w którym się tranzakcyja niedoszłego warszawskiego sejmu opisuje, z Warszawy de data Martii 1695, AGAD, Zbiór Branickich z Suchej, sygn. 41/55, k. 36v.

${ }^{16}$ Bieliński do Jana III, Czersk, 27 V 1695, NGAB, F. 695, op. 1, sygn. 66, k. 81-81a.

${ }_{17}$ Po sejmiku mozyrskim jeden z kandydatów do poselstwa pisał: „w konkurencyi poselstwa naszego, lubom ja nie był alienus od afektów braterskich musiałem [...] wm. pana i dobrodzieja cedować pisarzowi naszemu ziemskiemu, ważąc sobie pro summo łaskę pańską dobrodzieja mego". Por. Piotr Karol Kotowski, podkomorzy mozyrski do Dominika Słuszki, wojewody połockiego, Mozyr, 22 XI 1692, AGAD, Archiwum Roskie, Korespondencja, pudło LVIII, sygn. 144, s. 1.

${ }^{18}$ Stanisław Jabłonowski do NN [S. Szczuki ?], Lwów [?], 19 XII 1688, BCz, rkps 2715, s. 415-416.

19 NN. do S. Szczuki, [b.m. i d.], AGAD, APP, sygn. 163a, t. VII, s. 1-4.

${ }^{20}$ K. Szczuka, opat paradyski do S. Szczuki, Warszawa, 19 VI 1686, AGAD, APP, sygn. 163a, t. VI, s. 633-636; ostatecznie Franciszek Antonii Zapolski otrzymał nominację na stolnikostwo brzeskie, ale musiała mieć smak słodko-kwaśny, gdyż jednocześnie przywilej otrzymał prawdopodobnie Andrzej 
na sejmiku mścisławskim w latach 1690-1692 otrzymał urząd miejscowego chorążego ${ }^{21}$. Marcin Franciszek Smogulecki starosta nakielski, starając się o kasztelanię rogozińską, obiecywał nie tylko 300 zł, ale deklarował usługe publiczną oraz że „nigdy nie omieszka sejmików”22. Niektórzy magnaci w pogoni za urzędami prześcigali się w wyświadczaniu usług na sejmikach. Zaufany Ludwiki Karoliny Radziwiłłówny ostre sformułowania wymierzone w księżną zawarte w instrukcji dla posłów z sejmiku średzkiego tłumaczył konkurencją o pieczęć koronną ${ }^{23}$.

Dzięki nadaniom udało się skłonić do współpracy wiele osób. Cennym nabytkiem dworu był choćby Bogusław Uniechowski pisarz ziemski nowogródzki, który wraz z bratem Janem Michałem wójtem nowogródzkim był ważną postacią na miejscowym sejmiku ${ }^{24}$. Po otrzymaniu awansu na wojewodę trockiego pracował na sejmiku dla króla i robił to skutecznie, jak choćby w roku 1689, gdy zdaniem królewskich zaufanych „dobrze tam sejmik odprawił ten senator" ${ }^{25}$. Sejmik zakroczymski w czasach Jana III opanowany był przez rodzinę Lasockich, która według zachowanych danych z dziewięciu sejmików przedsejmowych, pełniła funkcje poselskie 16 razy, a tylko jeden raz posłem został przedstawiciel innej rodziny ${ }^{26}$. Pozyskanie lokalnych elit było zatem niezwykle istotne, o czym doskonale wiedzieli ludzie związani z dworem. Stanisław Szczuka pisał tak do króla: „Do pisarza nurskiego z umysłu wstępowałem upewniając go o słowach WKM, ledwie się starzec dał namówić do usługi publicznej, to pewna, że jest fidelissimus WKM"27. Pozyskanie wpływowych przyjaciół nie tylko pomagało dworowi, lecz uniemożliwiało również działania opozycji. Tak stało się na sejmiku kowieńskim w 1677 r., gdzie dwór osiągnął zdecydowaną przewagę. „Za niezjechaniem się jm. pana chorążego księstwa naszego na sejmik nie tak poszły rzeczy, jako sobie życzyliśmy [...] kiedy sprowadzić przyjaciół

Jaranowski. Por. Urzędnicy kujawscy i dobrzyńscy XVI-XVIII wieku. Spisy, oprac. K. Mikulski, W. Stanek, Kórnik 1990, s. 59-60.

${ }^{21}$ R. Kołodziej, Z królem czy z opozycją? Sejmik mścistawski w okresie rządów Jana III Sobieskiego [w druku].

${ }^{22}$ Wojciech Konstanty Breza, wojewoda poznański do Kazimierza Szczuki, opata paradyskiego, z Ludemic, 16 X 169[2], AGAD, APP, sygn. 163a, t. VI, s. 1109.

${ }^{23}$ Hrehory Oborski do konsyliarzy księżnej Ludwiki Karoliny, z Zabłudowa, 11 I 1689, AGAD, AR, dz. V, sygn. 10596, s. 22-26.

${ }^{24}$ Hrehory Oborski do konsyliarzy księżnej Karoliny z Radziwiłłów, z Zabłudowa, 11 I 1689 , AGAD, AR, dz. V, sygn. 10596, s. 22-26; zdaniem Oborskiego Uniechowski był na sejmiku nowogródzkim „omnipotens”.

${ }^{25}$ K. Szczuka, opat paradyski do S. Szczuki, Warszawa, 29 VI 1689, AGAD, APP, sygn. 163a, t. VI, s. $745-750$.

${ }^{26}$ Por. lauda i instrukcje sejmiku wyszogrodzkiego, BN PAU i PAN, rkps 8352, passim. Wplywy rodziny Lasockich na sejmiku zaczęły się pod koniec panowania Władysława IV lub w czasach Jana Kazimierza. Por. J. Choińska-Mika, Sejmiki mazowieckie w dobie Wazów, Warszawa 1998, s. 168-176.

27 S. Szczuka do Jana III, w Wiźnie, 19 XII 1687, NGAB, F. 695, op. 1, sygn. 100, k. 9-10a. 
jakąś niedolą nie mogłem” donosił z sejmiku Stefan Medeksza, tłumacząc się przed przywódcą opozycji litewskiej Michałem Kazimierzem Pacem² ${ }^{28}$.

Najlepiej sprawdzała się osobista działalność na sejmiku. W roku 1692 sejmik generalny pruski odbył się jedynie dlatego, że „dom ichm. panów Czapskich, w prowincji obszyrne koniunkcyje mający, siła około tego czynił starania, aby mógł mereri w łasce WKM i mnie tym samym evictorem suum utrzymać" ${ }^{29}$. Gdy zaufani królewscy nie zjawiali się osobiście, mogło to prowadzić do różnorakich perturbacji. Na przedsejmowym zjeździe witebskim związany z dworem kanclerz Dominik Radziwiłł starał się przeforsować na poselstwo kandydatury Teodora Łukomskiego i Adama Kisiela. Sam jednak na sejmiku nie mógł być obecny. Efektem tego była konieczność wyasygnowania przez kandydatów na posłów sporych sum pieniężnych, aby zagwarantować swój wybór $^{30}$. Przy staraniach o poselstwo należało zatem liczyć się niekiedy z dużymi wydatkami. Jan Kazimierz Worłowski, który został posłem z burzliwego sejmiku kowieńskiego w 1682 r. szczerze przyznawał: „gdzie się mam owego tysiąca upomnieć, który teraz na sejmiku, Pan Bóg zna, że klęknął”31. Jerzy Dominik Lubomirski został posłem z Lublina na sejm w roku 1695, lecz „ta dignitas wiele kosztowała, bo na częstowanie szlachty wyszło wina 20 beczek, dwa tysiące złotych na ryby, gdyż w sobotę solenną bankiet sprawiono i dwa tysiące złotych na ujęcie mieszających sejmikiem, jako i tych, którzy się albo porąbali, albo też, jeżeli który czapkę lub szablę zgubił”32. Franciszek Gałecki został posłem na sejmiku średzkim w 1682 r., ale przywiózł ze sobą sporo pieniędzy i zwyczajnie korumpował szlachtę. Za pomocą przywiezionych kilkuset dukatów próbował też przeciwdziałać wyborowi na posła Władysława Przyjemskiego, będącego w niełasce króla za zerwanie sejmu 1681 r. Te zabiegi dworu okazały się jednak bezskuteczne i Przyjemski mandat otrzymał ${ }^{33}$.

Z pewnością król oczekiwał od zaufanych senatorów wspierania postulatów dworu na sejmikach. Jeśli uchwalano niekorzystne punkty lub bez zgody dworu zrywano sejmik, oskarżenie mogło paść na lokalnego senatora, który powinien czuwać nad odpowiednim przebiegiem zjazdu. Gdy w roku 1687 zerwano sejmik wiszeński, hetman

${ }^{28}$ Stefan Franciszek Medeksza, podsędek kowieński do Michała Kazimierza Paca, wojewody wileńskiego, [b.m.], 7 XI 1677, RNB, F. 971, sygn. 311, nr 30, k. 81-82v.

${ }^{29}$ Jan Kos, wojewoda chełmiński do króla, w Łączyniu, 16 X 1692, NGAB, F. 695, op. 1, sygn. 142, k. 34-34a.

30 Teodor Łukomski i Adam z Brusiłowa Kisiel do Dominika Radziwiłła, kanclerza W. Ks. Lit., Witebsk 2 XII 1694, AGAD, AR, dz. V, sygn. 8674, s. 1.

${ }^{31}$ Jan Kazimierz Worłowski, podstarości kowieński do Stanisława Niezabitowskiego, podczaszego kaliskiego, z Zejm, 20 XII 1682, AGAD, AR, dz. V, sygn. 18019, s. 39.

32 Jerzy Koziński do Karola Radziwiłła, Warszawa, 18 XII 1694, AGAD, AR, dz. V, sygn. 7626, s. 88.

33 [Relacja Joachima Scultetusa], Neuteich, 24 XII 1682, Geheimes Staatsarchiv Preußische Kulturbesitz w Berlinie, I HA, Rep. 9, sygn. 27.e.6, k. 52-53v; Akta sejmikowe województw poznańskiego i kaliskiego. Lata 1676-1695, wyd. M. Zwierzykowski, R. Kołodziej, A. Kamieński, Poznań 2018, s. 294-295. 
Jabłonowski w liście tłumaczył, że został zerwany „lubom tam synów moich wyprawił”. Tłumaczenia hetmana, opisującego szczegółowo przyczyny zerwania zjazdu, jasno wskazują, że obawiał się oskarżeń ze strony dworu o zaniedbanie lub, co gorsza, współpracę z opozycją ${ }^{34}$. Ale i sami opozycjoniści bardzo często tłumaczyli się przed monarchą, udając niewinnych zerwania sejmiku czy jego niefortunnego przebiegu. W 1688 r. w taki sposób postąpił jeden z przywódców stronnictwa antykrólewskiego na Litwie, Benedykt Sapieha, po zerwaniu przedsejmowego sejmiku brzeskiego litewskiego, gdzie posłem miał zostać Jerzy Radziwiłł podczaszy litewski. Podskarbi litewski zapewniał króla, że nie jest autorem rozerwania sejmiku, a ponadto obiecywał przybyć na powtórny sejmik i dopomóc w obraniu na poselstwo Jerzego Radziwiłła ${ }^{35}$.

Król był doskonale zorientowany w wydarzeniach sejmikowych, gdyż na wielu z nich miał konfidentów, którzy - w zamian za pensje lub obietnice innych korzyści - donosili nie tylko o jego wynikach, ale i szczegółowo o przebiegu, w tym również o osobach wypowiadających się nie po myśli dworu. Hieronim Poniński po sejmiku w Środzie tłumaczył się ze swoich słów przed podskarbim Marcinem Zamoyskim: „jeżelim co mówieł na sejmiku, mówiłem to, co właśnie należało do obrony R.P. i praw naszych, ale żebym miał directe do Państwa mówić, tego mi nikt cnotliwy nie zada”. Oskarżał też ludzi, którzy „nic nie robą na sejmikach, tylko poczciwość szlachecką notują, a nie mając się czym przysłużyć, biorąc za to corocznie pensyje, żeby szalbierowali, choć się i o tym nie śni, to oni opisują" ${ }^{\text {"36. }}$

Królewskim człowiekiem na sejmiku w Środzie był Franciszek Gałecki ${ }^{37}$. O wynikach obrad donoszono również królowiz drugiego górnego sejmiku koronnego, z Proszowic, skąd królewskim informatorem był Stanisław Druszkiewicz kasztelan chełmski ${ }^{38}$. Z Wiszni szczegółowe informacje przekazywał królowi młody Jan Stanisław Jabłonowski, który udostępniał również „haki” na opozycję, pisząc, że „posłowie zaś sejmowi, jeżeli nie wszyscy godni, znajdzie się sposób, któren opowiem, kiedy mię szczęście to podka, tryumphalne WKM pocałować nogi" ${ }^{39}$. Z Wielunia nieznany szlachcic nie

${ }^{34}$ Stanisław Jabłonowski do NN [S. Szczuki?], Lwów [?], 19 XII 1688, BCz, rkps 2715, s. 415-416.

${ }^{35}$ Jan III do Jerzego Radziwiłła, podczaszego W. Ks. Lit., Warszawa, 1 I 1688, AGAD, AR, dz. III, sygn. 16, s. 95-96; król informował, że rozmawiał z podskarbim w. lit. o zerwanych sejmikach, „który protestatur, że nie był okazyją, aby się brzeski litewski miał był spadać. Co, aby samą utwierdził rzeczą, ochotnie się deklaruje i ofiaruje, że sam in persona zjedzie na powtórny i tak rzeczy dobrze disponet, że uprz. w. na poselstwo skutecznie dopomoże"; sejmik powtórny został jednak również zerwany. Por. D. Konieczna, Ustrój i funkcjonowanie sejmiku brzesko-litewskiego w latach 1565-1763, Warszawa 2013, s. 173.

${ }^{36}$ Hieronim Poniński, cześnik do Marcina Zamoyskiego, Poznań, 16 XI 1686, AGAD, Archiwum Zamoyskich, sygn. 483, s. 118-119; Akta sejmikowe województw poznańskiego i kaliskiego, s. 377-378.

${ }_{37}$ Akta sejmikowe województw poznańskiego i kaliskiego, passim.

38 Stanisław Druszkiewicz, kasztelan chełmski do Jana III, w zamku niemirowskim, 26 VIII 1692, NGAB, F. 695, op. 1, sygn. 48, k. 53-54a.

39 S. Jabłonowski do Jana III, Lwów, 14 XI 1692, NGAB, F. 695, op. 1, sygn. 99, k. 41-41a. 
tylko zapewniał, że promował na sejmiku „zalecony mu interes”, ale donosił również o uczestnikach zjazdu: „Nie omyliłem się na zdaniu moim, asekurując WKM PMM de integritate et fidelitate pana starosty wieluńskiego, bo ten żadnych paszkwilów ani listów nie rozsyłał ani rozdawał, ale o niech cale nie wie”ł0. Miał król też informatorów na Litwie. Na Żmudzi wiernym i zaufanym „partyzantem” Sobieskiego był Andrzej Kryszpin Kirszenstein, z kolei z Mścisławia szczegółowe informacje przysyłał Kazimierz Mironowicz Szpilowski podsędek miński ${ }^{41}$.

Doniesienia docierające do dworu obejmowały nie tylko informacje o wybranych posłach, ale również o uchwalonych instrukcjach. W omawianych czasach zdarzało się, że często gotowe punkty przywożono na sejmiki, co czynił zarówno dwór, jak i opozycja. Król w liście do nominata gnieźnieńskiego Stefana Wydżgi wspominał, że punkty z wielu instrukcji przed pierwszym sejmem grodzieńskim nie stanęły na sejmikach, ale były „w kącie domowym formowane” ${ }^{\prime 2}$. Monarcha postępował podobnie, starając się wpływać poprzez zaufanych na treść spisywanych przez szlachtę instrukcji sejmikowych. Stanisław Witwicki biskup kijowski zapisał: „Podkanclerzy pisze mi, żeś wm. pan miał dać particulares informationes do skoncypowania instrukcji sejmikowej”ł3. O wpływaniu dworu na sejmiki świadczy zachowany dokument „Punkta na sejmiki przysłane 26 marca 1678 r. w Bystrzycy”. Treść dokumentu wskazuje, że powstał w otoczeniu króla i zawierał wytyczne, jakie punkty należy promować na sejmikach litewskich i co powinno znaleźć się w instrukcjach poselskich. Propozycje te były zdecydowanie wymierzone w Paców ${ }^{44}$. Podobny zachowany odpis to „Punkt do instrukcji na Pan Bóg przyszłym sejmie”, w którym zapisano postulaty obrony „ius patronatus” króla polskiego i ostro atakowano nuncjusza ${ }^{45}$. Skrypt ten powstał zapewne w otoczeniu dworu i miał być prawdopodobnie forsowany na sejmikach przedsejmowych. $\mathrm{Na}$ sejmikach litewskich przed drugim sejmem 1693 r. były promowane „Punkta do obrady publicznej i zachowania całości dobra pospolitego należące, które na sejm teraźniejszy następujący w instrukcyją wpisane ichm. panom posłom do promowania skutecznego zlecone być mają"æá.

Część uchwalanych na sejmikach instrukcji docierała do rąk króla, co więcej, zdarzało się, że mógł dokonywać w nich zmian - czy to samodzielnie, czy przez zaufanych.

${ }^{40}$ NN do Jana III, z Mstowa, 4 XII b.r. [169?], NGAB, F. 695, op. 1, sygn. 48, k. 112-113a.

${ }^{41}$ Kazimierz Mironowicz Szpilowski, podsędek miński do króla, Mścisław, 18 XII 1687, NGAB, F. 695, op. 1, sygn. 55 , k. 28-28v.

${ }^{42}$ Jan III do Wydżgi, nominata gnieźnieńskiego, [b.m. i d.] [1678], Wojewódzka Biblioteka Publiczna w Lublinie, sygn. 628, s. 108-113.

43 Stanisław Witwicki, biskup kijowski do NN, [b.m.] [Warszawa], 15 XI 1680, AGAD, AR, dz. V, sygn. 17574 , s. 46.

${ }^{44}$ Punkta na sejmiki przysłane d. 26 VIII 1678 w Bystrzycy, AGAD, AR, dz. II, sygn. 1673, s. 1-4.

45 Punkt do instrukcyjej da Pan Bóg na przyszły sejm, BN PAU i PAN, rkps 370, k. 26v-27.

46 BN PAU i PAN, rkps 6121, k. 51-52v. 
W roku 1692 S. Szczuka przesłał Sobieskiemu instrukcję lubelską z informacją, że „instrukcyja nasza jeszcze nie podana do grodu, jeśli by co divinae mentu WKM interea”7. Do interesującej sytuacji doszło w Pińsku w 1688 r., gdzie miejscowy starosta wpisał do ksiąg grodzkich instrukcję, w której „nalazły się takowe punkta, które na sejmiku proponowane nie były”. Wszystkie kontrowersyjne zapisy były w interesie dworu i jego ludzi. Co więcej, miejscowy starosta nie pozwolił szlachcie wnieść do grodu pińskiego protestacji, dlatego wniosła ją do urzędu w Brześciu Litewskim ${ }^{48}$.

Czasem nie udawało się zapobiec wprowadzeniu do instrukcji niekorzystnych punktów, czy zapewnić wyboru samych zaufanych posłów, wówczas najczęściej dwór szedł na kompromis. Nawet niezwykle skuteczny Stanisław Szczuka nie był niekiedy w stanie zagwarantować pełnego sukcesu - np. w instrukcji wiskiej z 1687 r. znalazł się punkt niekorzystny dla króla, gdyż Szczuka ustąpił pod naciskiem całej ziemi ${ }^{49}$. Z kolei z sejmiku łęczyckiego w roku 1692 prymas Michał Radziejowski donosił, że nie dało się wybrać wszystkich przychylnych królowi, gdyż „musiał stanąć pan Iwański, alias by się był [sejmik] zerwał, ale mu się dwóch posłów, domowych moich, przydało" 50 .

Gdy natomiast nie udawało się wpłynąć na sejmik, można było spróbować go zerwać. Nie ma co do tego żadnych wątpliwości, że i zaufani królewscy, podobnie jak opozycja, rwali sejmiki. W 1688 r. z sejmiku sochaczewskiego posłem chciał zostać niejaki Wojciech Morski, „człowiek młody i płochy”, który „zebrawszy piwny zaciążek zjechał na sejmik" i próbował hasłami antykrólewskimi podburzyć szlachtę. Stronnictwo królewskie w osobie miejscowego starosty było jednak czujne i sejmik zerwało ${ }^{51}$. W $1681 \mathrm{r}$. zerwano sejmik lidzki, aby nie dopuścić do wpisania w instrukcję punktów niekorzystnych dla króla ${ }^{52}$. W każdym razie oskarżenia o zrywanie z inspiracji dworu sejmików krążyły po kraju, docierając również do uszu królewskich ${ }^{53}$.

Po zerwaniu sejmiku można było mieć nadzieję, że sejmik powtórny zakończy się z lepszym skutkiem. Czasy Jana III to bowiem okres, gdy po raz pierwszy na wielką skalę wydawano powtórne uniwersały po zerwanych sejmikach przedsejmowych. Kancelaria królewska wcześniej przygotowywała się na takie ewentualności, zawczasu wypisując

${ }^{47}$ S. Szczuka do króla, w Radzynie, 5 XII 1692, NGAB, F. 695, op. 1, sygn. 100, k. 131-133.

48 Manifestacja obywateli powiatu pińskiego przeciwko instrukcji zaniesionej 5 XI 1688, NGAB, F. 1705 (Księgi grodzkie brzeskie), op. 1, sygn. 109, k. 1448-1449a.

49 S. Szczuka do Jana III, w Wiźnie, 19 XII 1687, NGAB, F. 695, op. 1, sygn. 100, k. 9-10a.

${ }^{50}$ Michał Radziejowski do króla, Skierniewice, 1 XII 1692, NGAB, F. 695, op. 1, sygn. 142, k. 44.

51 Jan Oborski, starosta sochaczewski do S. Sarnowskiego defert o sejmiku zerwanym i o uniwersał na powtórny prosi, w Czerwonce, 7 X [prawdopodobnie: XI] 1689, BCz, rkps 1376, s. 655-656.

52 Dominik Radziwiłt, podkanclerzy lit. do króla, Nowogródek, 29 VII 1681, NAGB, F. 695, op. 1, sygn. 142, k. 11-11a.

53 Jan III do Jana Chryzostoma Pieniążka, wojewody sieradzkiego, Warszawa, 27 I 1688, BCz, rkps 422, s. 239-241; król w liście wyrażał oburzenie na krążące plotki, że Melchior Grudziński kasztelan sieradzki miał z inspiracji dworu doprowadzić do zerwania sejmiku sieradzkiego. 
dodatkowe uniwersały z okienkami na nazwę sejmiku i datę zwołania. Co interesujące, zawierały one ogólną formułę, w której król wyrażał żal, że pierwszy sejmik nie doszed1 $^{54}$. Jeśli zaufani dworscy prosili o pow tórne uniwersały, najczęściej zapewniali, że na pow tórnym sejmiku „te staną subiecta, które omni studio WKM będą umiały służyć” 55 . Dlatego starano się, aby o sejmiku powtórnym nie powiadamiać całej szlachty, a jedynie zaufanych. Zdarzało się zapewne często, że uniwersału nie oblatowano w grodzie lub czyniono to w ostatniej chwili, często w dzień inauguracji obrad sejmiku. W 1688 r. król dał powtórny uniwersał na sejmik szadkowski Melchiorowi Grudzińskiemu kasztelanowi sieradzkiemu, który go, jak żaliła się niewtajemniczona szlachta, „pod znakiem woli lub dyskrecyjej swojej trzyma" ${ }^{56}$. Powtórny sejmik czernihowski kilkakrotnie organizowano w dużym pośpiechu i pewnie w tajemnicy ${ }^{57}$. W 1693 r. po dwóch zerwanych sejmikach wołyńskich, w tajemnicy zorganizowano trzeci, nie podając uniwersałów do grodu łuckiego. Zaskoczona szlachta szukała uniwersału również w grodzie włodzimierskim, a gdy go nie znalazła, złożyła protestację $e^{58}$ W roku 1687 Dominik Radziwiłł podkanclerzy litewski ostrzegał króla przed oddaniem powtórnego uniwersału na sejmik nowogródzki w nieodpowiednie ręce, pisząc, że opozycja jest przygotowana do powtórnego zjazdu i ma listę osób do promowania na poselstwo. „Za czym trzeba mieć WKM na to oko, abyś WKM PNM wiedział, komu powierzał onych i na czyje ręce dał”. Informował też, że rozsyła swoich subiektów po zerwanych sejmikach litewskich, które mają być zwołane powtórnie ${ }^{59}$. Po zerwaniu sejmiku łuckiego w 1688 r., na którym posłem miał być Jerzy Radziwiłł podczaszy lit., Karol Radziwiłł podkanclerzy lit. wspólnie z królem naradzali się, skąd mógłby zostać posłem ${ }^{60}$. Narada polegała na analizie, który sejmik został zerwany i na który należałoby wydać powtórny uniwersał. Mimo tych działań, nie miał jednak nigdy król pewności, kto zostanie wybrany na powtórnym sejmiku i niejednokrotnie były to osoby nieprzychylne wobec dworu

${ }^{54}$ Uniwersał Jana III na sejmik powtórny, [b.d.] 1692, RNB, F. 971, sygn. 66, nr 27, k. 52. Formularz ten zawiera ogólne zwroty o zerwanym sejmiku i okienka na wstawienie nazwy ziemi i dat.

${ }_{55}$ Zygmunt Dąmbski, wojewoda brzeski do króla, w Lubrańcu, 5 XII 1694, NGAB, F. 695, op. 1, sygn. 55, k. 179.

56 Jan Odrowąż Pieniążek do Jana III, w Proszkowie [?], 19 I 1688, NGAB, F. 695, op. 1, nr 142, k. 1-1a.

${ }^{77}$ R. Kołodziej, Attitudes of the Kiev, Bratslav and Chernibiv Dietines in Exile Towards the Policy of John III Sobieski in the Period of 1687-1691, „Res Historica” 2020, No. 49, s. 229-263, https://doi.org/ 10.17951/rh.2020.49.229-263; idem, The Kiev, Bratslav, Chernihiv Exiles and the Policy of John III Sobieski in the Years 1692-1695, „Res Historica” 2020, No. 50, s. 141-169. https://doi.org/10.17951/ rh.2020.50.141-169

${ }^{58}$ Protestacja Stanisława Iwanickiego, łowczego nowogródzkiego, obywatela województwa wołyńskiego, 22 XII 1693, CDIAU, F. 28, księgi grodzkie włodzimierskie, op. 1, sygn. 138, k. 638v-639.

59 D. Radziwiłl, podkanclerzy lit. do Jana III, AGAD, AR, dz. II, ks. 25, s. 134-137.

${ }^{60}$ Jan III do Karola Radziwiłła, koniuszego lit., Żółkiew, 17 XI 1688, AGAD, AR, dz. III, sygn. 7 , s. 12-13; kopia listu por. BCz, rkps 182, s. 283. 
(np. powtórny sejmik kowieński w 1685 r.). Zapewne z tych powodów zdarzało się królowi nie wydawać powtórnych uniwersałów. Po zerwaniu sejmiku lubelskiego jesienią roku 1688 król nie zgodził się na drugi sejmik i nie wydał odpowiednich dokumentów, tłumacząc się brakiem pieczęci na dworze. Prawdziwe powody były jednak inne, gdyż szlachta na zerwanym sejmiku lubelskim ostro krytykowała monarchę, zarzucając mu celowe rozlokowanie wojsk w dobrach ziemskich. Nieodpowiednio potraktowany miał być poseł królewski do Lublina, co więcej, szlachta szukając na siłę oznak naruszenia prawa, zarzuciła, że uniwersał królewski miał być opatrzony pieczęcią pokojową „lubo de facto była koronna”. Tak więc w tym przypadku odmowa wydania powtórnego uniwersału była spowodowana antykrólewskim nastawieniem samej szlachty ${ }^{61}$. Na pewno nie wydano uniwersału na powtórny sejmik żmudzki w 1694 r., gdyż dwór, w przeciwieństwie do opozycji, stał na stanowisku, że sejmik się odbył, tym bardziej, iż wybrał na posłów zaufanych króla.

Z przytoczonych, fragmentarycznych danych wynika, że Jan III Sobieski był osobą niezwykle aktywną w polityce wewnętrznej. Nie był z pewnością bezradny wobec działającej w kraju opozycji i w jakimś zakresie wykorzystywał możliwości, jakie dawały mu królewskie prerogatywy. Pojawiające się w literaturze tezy o zdominowaniu kraju przez wszechwładnych opozycjonistów wymagałaby przemodelowania, bo przykładów tego typu twierdzeń znaleźć można wiele. Dla zobrazowania warto przytoczyć jedno z nich. Zbigniew Wójcik zauważył, że wielu żołnierzy pod koniec lata 1688 r. za zgodą hetmana Jabłonowskiego opuściło obóz nad Dniestrem, aby udać się na sejmiki. Znakomity znawca czasów Sobieskiego interpretuje to jednak w sposób wysoce kontrowersyjny, dowodząc, że dla towarzyszy „ważniejszy bowiem był [...] udział w kampanii

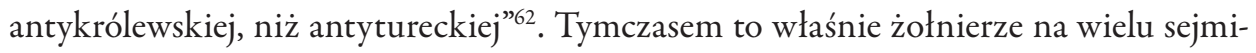
kach stanowili naturalne zaplecze obozu dworskiego. Opisywana sytuacja miała miejsce przed sejmem warszawskim 1688-1689, gdy Sobieski przygotowywał się do rozprawy z opozycją i prowadził niezwykle aktywną politykę na sejmikach zarówno koronnych, jak i litewskich. Udział żołnierzy w obradach był więc zapewne częścią strategii dworu.

Z przedstawionych przykładów wynika, że król starał się kontrolować sejmiki i doceniał ich znaczenie. Jego działania miały zapewnić mu odpowiednie zaplecze w sejmie i należy uznać, że były w jakimś zakresie skuteczne. W izbie poselskiej stronnictwo prokrólewskie zawsze posiadało przewagę liczebną. Aby jednak precyzyjniej ocenić skalę zjawiska oddziaływania dworu na szlacheckie zjazdy, należałoby badać każdy sejmik oddzielnie. $Z$ zebranych informacji wynika, że w walce politycznej ani król, ani jego zaufani nie wahali się postępować niezgodnie z prawem, wykorzystując wszystkie niedoskonałości staropolskiego systemu parlamentarnego. To nasuwa jednak

${ }^{61}$ Stanisław Szczuka do Marcina Zamoyskiego, Pilaszkiewicze, 10 XII 1688, Archiwum Polskiej Akademii Nauk, III-198 (Teki Janusza Wolińskiego), sygn. 70, k. 276.

${ }^{62}$ Z. Wójcik, Jan Sobieski, s. 444. 
pytanie badawcze, na ile królowi mogło zależeć na gruntownej reformie systemu parlamentarnego. Na pewno z punktu widzenia dobra państwa ocena działań dworu w dłuższej perspektywie zdaje się przynajmniej dwuznaczna.

\begin{abstract}
Jan III Sobieski was active in the domestic policy. He tried to influence pre-parliament dietines so they would elect the King's sympathetic parliamentarians and to take into account instructions advantageous to the Court. There was lot of assembly in Polish-Lithuanian Commonwealth and the King needed many supporters - senators and local noble elites. However, he had a wide range of possibilities on how to win them. People trusted by the Court attended the dietines personally or through their family and political friends. They reported to the King on the results of deliberations, made sure people elected as deputies were recommended by the Monarch and there weren't disadvantages for the Court in an instruction. Of course, the Court didn't win the political fight everywhere. Sometimes a compromise with the opposition was necessary. Occasionally Court's supporters interrupted a dietine to not allow the opposition to win. The King convened often a second dietine, which was sometimes held in secret, with a small circle of trusted people. The methods used by the King weren't different from methods of opposition and Sobieski took advantage of the cracks in the parliamentary system of Polish-Lithuanian Commonwealth.
\end{abstract}

\title{
Keywords
}

Polish-Lithuanian Commonwealth, Jan III Sobieski, dietines (assembly), parliament, political struggle. 